\title{
Beneficiary contact moderates relationship between authentic leadership and engagement
}

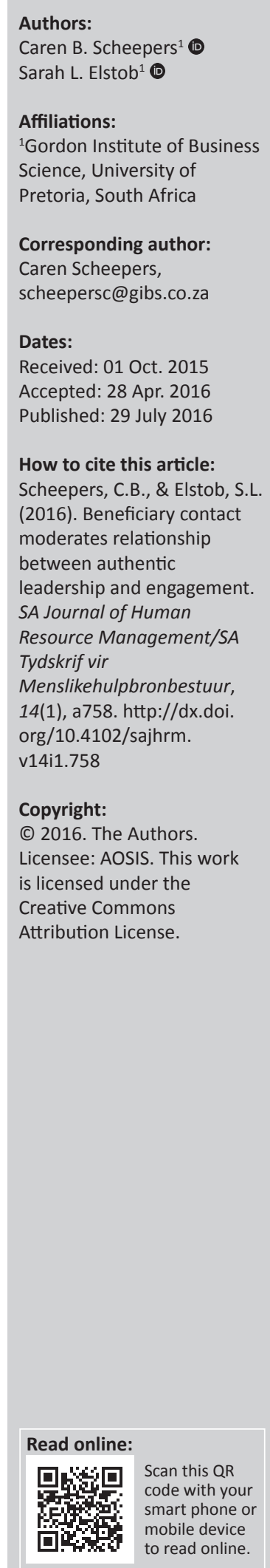

Orientation: Beneficiary contact moderates the relationship between authentic leadership and work engagement.

Research purpose: The objective of this study was to examine the moderating effect of the breadth, depth and frequency of employee interaction with the beneficiaries of their work on the positive impact of authentic leadership on work engagement.

Motivation for the study: Investigating the boundary conditions of the relationship between leaders and followers is vital to enhance the positive effect of leadership. Authentic leadership has not previously been examined with respect to beneficiary contact as a specific situational factor. The researchers therefore set out to ascertain whether beneficiary contact has a strengthening or weakening effect on the impact of authentic leadership on work engagement.

Research design, approach and method: The researchers administered the Authentic Leadership Questionnaire (ALQ), the Utrecht Work Engagement Scale (UWES-9) and Grant's scale on Beneficiary Contact.

Main findings: The findings showed that beneficiary contact had a weakening effect on the positive relationship between authentic leadership and work engagement.

Practical/managerial implications: Ideally, organisations create environments conducive to work engagement in which leadership plays an important role. This study found that one factor in the work environment, namely beneficiary contact, might have an adverse effect on the positive relationship that authentic leadership has on work engagement. Leaders should therefore take organisational contextual realities into account, such as regular, intense interaction of employees with the beneficiaries of their work. This situation could create strain for individual employees, requiring additional organisational support.

Contribution/value-add: Organisations need to recognise the impact of beneficiary contact on the relationship between authentic leadership and work engagement. The researchers propose further studies on the influence of contextual variables on the relationship between leaders and followers.

\section{Introduction}

Authentic leadership has a positive impact on followers, particularly when it comes to work engagement (Avolio \& Gardner, 2005; Ilies, Morgeson \& Nahrgang, 2005). Leader-follower relationships, however, are not cultivated in a vacuum (Porter \& McLaughlin, 2006). Investigating the conditions of the relationship is therefore vital to understanding how to enhance the effect of authentic leadership in the work environment. In this regard, Cooper, Scandura and Schriesheim (2005) as well as Gardner, Cogliser, Davis and Dickens (2011) encourage research into the role of moderators in the relationship between authentic leadership and followers' attitudes and performance. This is in line with contingency theories (House, 1971) which suggest that leaders need to adjust to situational factors. Investigating the impact of individual situational factors in the work environment is instrumental in increasing the effectiveness of leadership practices. Authentic leadership has been examined quite extensively with regard to situational leadership factors. It has not, however, been investigated with regard to beneficiary contact, or the extent to which employees are exposed to interaction with the beneficiaries or customers, of their work outputs. Grant (2012) recommends research into whether beneficiary contact has a moderating role in leadership styles other than transformational leadership. In Grant's studies, the effect of transformational leadership on employees' performance was strengthened through beneficiary contact (Grant, 2012). In contrast, other studies on interaction with beneficiaries reveal that emotionally intense exchanges could lead to negative consequences, like strain and ultimately 
burnout (Grant \& Parker, 2009). This study therefore focused on ascertaining if beneficiary contact has a strengthening or weakening impact.

Another key construct in this study was employee engagement as it increases employee performance (Anitha, 2014; Salanova, Agut \& Peiró, 2005) and results in several other positive outcomes (Burke \& El-Kot, 2010), such as profitability, customer satisfaction and loyalty (Gallup, Inc., 2013; Harter, Hayes \& Schmidt, 2002) and organisational citizenship behaviour (Rich, Lepine \& Crawford, 2010) and results in competitive advantage for the organisation (Shuck, Reio \& Rocco, 2011). Work engagement, rather than performance, was selected for this study because of this wider scope of benefits. Although increasing levels of engagement is beneficial for organisations, studies have shown worldwide engagement levels to be low (Gallup, Inc., 2013; Towers Watson, 2012).

Organisations need to invest in leadership development (Avolio, Reichard, Hannah, Walumbwa \& Chan, 2009; Avolio, Walumbwa \& Weber, 2009; George, 2003) because of the negative impact of destructive leadership (Padilla, Hogan \& Kaiser, 2007). Most studies revolve around the leadermember exchange (Yukl, O’Donnell \& Taber, 2009), yet leader-follower relationships are embedded within organisational contexts (Pawar \& Eastman, 1997) that can be conducive or detrimental to effective leadership (Padilla et al., 2007). Porter and McLaughlin (2006) ask whether:

researchers adequately investigate the relationship between organisational context components and leadership? Or, like with the weather, many are talking about it, but few are doing much about it, insofar as empirical research is concerned. (Porter \& McLaughlin, 2006, p. 559)

Avolio (2007) also promotes a change in the focus of leadership development and research, from individual leaders' characteristics to leadership as a complex social dynamic construct. Lord and Hall warned as far back as 1992 against research on complex issues of leadership using simple bivariate correlations. Researchers have established that organisational factors influence positive leadership specifically, leading to an inclusive, strength-based climate (Gardner, Avolio, Luthans, May \& Walumbwa, 2005; Gardner, Cogliser, Davis \& Dickens, 2011) or organisational structure (Porter \& McLaughlin, 2006) and context also influences charismatic leadership (Shamir \& Howell, 1999). In 1991 Tosi advised researchers in 'The Leadership Quarterly' to focus leadership research on the organisation as context for leadership theory and Bass reiterated this in 1999 (Bass, 1999). Porter and McLaughlin (2006) proclaimed a resounding 'yes' to the question of whether research was neglecting the organisation as the context for leadership. They reported that only $16 \%$ of 373 peer-reviewed articles had taken the organisational context into account. Koene, Vogelaar and Soeters (2002, p. 194) warned that, 'There is a lack of empirical information on the moderating effect of the organisational context on leadership effectiveness'. Although Walter and Bruch's (2010) research did emphasise that organisational design choices, like centralisation in decision-making, create conditions for the emergence of transformational leadership behaviour, most leadership studies that investigate moderators examine task interdependence, task competence and task complexity (Day, Gronn \& Salas, 2004). Uhl-Bien, Marion and McKelvey (2007) emphasises that leadership is embedded in a complex interplay of numerous interacting forces and warns not to underestimate the complexity of the context in which organisations must function and adapt. Against the background of these recent findings, this study opted to investigate a particular contextual dynamic, namely the moderating effect of employees' exposure to the people affected by their work (in other words, their beneficiaries). Interestingly, in a number of studies, beneficiary contact increased persistence behaviour (Belle, 2012; Grant, 2007). Parker and Axtell (2001) find beneficiary contact results in stronger commitments and, in their later studies, a greater tendency to take the customer's perspective (Axtell, Parker, Holman \& Totterdell, 2007). An alternative view, the emotional labour and burnout perspective, shows negative outcomes of beneficiary contact, such as strain, stress and burnout (Grandley \& Diamond, 2010; Grant \& Parker, 2009).

\section{Purpose}

Against this background the purpose of this research was to answer the research question: 'what is the strengthening or weakening (moderating) effect of beneficiary contact on the impact of authentic leadership on work engagement?'

\section{Literature review}

\section{Authentic leadership}

Authenticity involves both owning one's personal experiences and acting in accordance with one's true self (Gardner et al., 2005; Leroy, Palanski \& Simons, 2012). Interest in authentic leadership emanated from a proposition that transformational leaders are pseudo versus authentic (Bass \& Steidlmeier, 1999). Pseudo transformational leaders can be branded as immoral, whereas authentic transformational leaders 'expand the domain of effective freedom, the horizon of conscience and the scope for altruistic intention' (Bass \& Steidlmeier, 1999, p. 211). Authentic leaders are, however, not necessarily transformational leaders, 'the key distinction is that authentic leaders are anchored by their own deep sense of self, they know where they stand on important issues, values and beliefs' (Avolio \& Gardner, 2005, p. 329). In this study, four subconstructs of authentic leadership were investigated. The first was balanced processing, that refers to:

listening to multiple sources and stakeholders before making a decision; second, internalised moral perspective refers to being guided by internal moral standards that are used to self-regulate one's behaviour; third, relational transparency refers to presenting one's authentic self through openly sharing information and feelings as appropriate for situations; and fourth, self-awareness refers to demonstrated understanding of one's strengths, weaknesses and the way one makes sense of the world. (Avolio, Walumba \& Weber, 2009, p. 424) 
Research has shown evidence of a positive relationship between authentic leadership and work engagement, and that investment in developing authentic leaders is therefore essential (Avolio, Gardner, Walumbwa, Luthans \& May, 2004; Gardner et al., 2011; Hassan \& Ahmed, 2011; Ilies et al., 2005; Shamir \& Eilam, 2005). This research study formulated the following hypothesis to determine whether the data of this study supports the outcomes of previous studies:

- Hypothesis 1: Authentic leadership has a linear relationship with work engagement.

\section{Work engagement}

Engagement is an important focus of the research into positive psychology (Schaufeli, Bakker \& Salanova, 2006; Seligman \& Csikszentmihalyi, 2000). Four major strands of engagement research have emerged concerning personal engagement, burnout, employees with an energetic connection and employee perceptions. The first, personal engagement, relates to individuals who 'employ and express themselves physically, cognitively and emotionally' (Kahn, 1990, p. 694). Later researchers confirmed Kahn's study and that psychological meaningfulness or employees experiencing a return on investment of their work performance were an important condition for personal engagement (Simpson, 2009). The original burnout to engagement scale of Maslach, Jackson and Leiter (1996) suggests that engagement lies at the opposite end of the scale to burnout (Demerouti, Mostert \& Bakker, 2010; Maslach, Leiter \& Jackson, 2012). The third strand involves work engagement, where 'employees have an energetic connection with their work and employee engagement' (Schaufeli et al., 2006, p. 702) and the fourth, employee engagement, involves measures of employee perceptions of work characteristics (Attridge, 2009; Harter et al., 2002; Saks, 2006). In this study, the researchers focused on the third strand of engagement, namely work engagement. Scholars such as Llorens, Bakker, Schaufeli and Salanova (2006) established work engagement, for example, as a mediator of the relationship between the job resources available to employees and their organisational commitment, whereas van den Heuvel, Demerouti, Bakker and Schaufeli (2013) and Xanthopoulou Bakker, Demerouti and Schaufeli (2012) also emphasised the role of contextual and personal job resources. Other scholars paid attention to identifying the organisational antecedent conditions that result in engagement. These findings focus managerial efforts on fostering engagement in the workplace. A number of scholars investigated the influence of job resources and job demands (Bakker \& Demerouti, 2007) but came up with conflicting findings (Crawford, LePine \& Rich, 2010). Another organisational factor was suggested by Grant (2007). He identified a relationship between the level of engagement that employees experience towards their work and the extent to which they were exposed to the beneficiaries of their work. The researchers therefore included this variable in their study:

- Hypothesis 2: Beneficiary contact has a moderating effect on the impact of authentic leadership on the individual constructs of work engagement, (1) vigour, (2) dedication and (3) absorption.

\section{Beneficiary contact}

Beneficiary contact is:

the degree to which jobs and tasks are relationally structured to provide employees with opportunities for exposure to and interactions with the living, breathing human beings affected by their work. (Grant, 2007, p. 398)

It allows employees to see their organisation's goal being achieved when they serve the beneficiaries of their work (Grant et al., 2007) and it greatly enhances their persistence, output, productivity and vigilance (Belle, 2012). In job design research, the capacity of beneficiary contact to enhance employee motivation has received extensive recognition (Grant et al., 2007). Three empirically distinct dimensions of the contact with beneficiaries were investigated in this study, namely contact frequency, breadth and depth. Contact frequency:

represents how often the job provides opportunities to regularly interact with beneficiaries, second, contact breadth - the degree to which the job provides opportunities to interact with a variety of different beneficiaries, and third, contact depth is the degree to which the job provides opportunities for meaningful interactions with beneficiaries. (Grant, 2008, p. 22)

The researchers, therefore, formulated the following hypothesis:

- Hypothesis 3: The individual constructs, (1) frequency, (2) breadth and (3) depth of beneficiary contact have a strengthening effect on the impact of authentic leadership on work engagement.

Two competing perspectives on beneficiary contact have emerged in recent literature. The first is the emotional labour and burnout (EL) perspective, which holds that frequent, direct, emotionally intense interactions with clients, customers and patients are likely to cause strain, stress and burnout (Bennett \& Barkensjo, 2005; Grant \& Parker, 2009). A vast array of negative personal impacts is likely to involve unpleasant contact and internal conflict (Grandley \& Diamond, 2010; Grandley, Kern \& Frone, 2007). The second, the relational job design perspective, argues that:

when jobs are structured to provide employees with contact with beneficiaries, employees can empathise, identify with and take the perspective of beneficiaries and thereby develop stronger affective commitments to them. (Grant \& Parker, 2009)

The more frequent the communication, the lower the role ambiguity and the higher the perceived task significance (Humphrey, Nahrgang \& Morgeson, 2007). Given these research findings and Grant's studies revealing the strengthening effect of beneficiary contact on the impact of transformational leadership on employees' performance (Grant, 2012), the researchers proposed that the relationship between authentic leadership and employee engagement would be strengthened by beneficiary contact. 


\section{Method}

\section{Research approach}

This study examined causal relationships between the independent variable, authentic leadership; the moderator, beneficiary contact; and the dependent variable, work engagement. Original survey data was required on these constructs (Saunders \& Lewis, 2012). The researchers chose existing questionnaires to ensure validity of the measures.

\section{Measures}

\section{Research participants}

The target population and unit of analysis of the study included all full-time employees in specific business units of two financial services companies: Company A and an outsourced administration company, Company B. The population was composed of 127 employees from Company A and 298 employees from Company B. The number of respondents from Company A was 93 (73\% response rate) and 12 responses were incomplete. Company B had 35 respondents $(12 \%$ response rate) with 12 incomplete responses. Only 81 of the Company A responses were deemed reliable and included in the study. The majority of these respondents had been working for the company for $0-4$ years (16 had tenure of $0-2$ years and 21 had tenure of $2-4$ years), whereas a large proportion of respondents had tenure of 10 years or more. Of the 81 respondents, there were 47 females (58\%) and 34 males (42\%).

\section{Measuring instruments}

The instruments all used the Likert-type scale, featuring five anchors, from strongly agree to strongly disagree with the statement.

\section{Authentic leadership}

The researchers used the '16-item' Authentic Leadership Questionnaire (Copyright ${ }^{\odot} 2007$ Authentic Leadership Questionnaire ALQ) by Avolio, Gardner and Walumbwa (2007) distributed by Mind Garden Inc. (Walumbwa, Avolio, Gardner, Wernsing \& Petersen, 2008). The researchers obtained written permission for use of the ALQ from the creators, Mindgarden. An example of the statements is, 'my leader says exactly what he/she means'.

\section{Work engagement}

The researchers measured work engagement using the '9-item' Utrecht Work Engagement Scale (UWES-9) (Schaufeli et al., 2006) (Schaufeli, Salanova, Gonzalez-Roma \& Bakker, 2002). Examples of statements include, 'I am immersed in my work' and 'To me, my job is challenging'.

\section{Beneficiary contact}

The researchers used Grant's three 3-item scales (Grant, 2008). Morgeson's questionnaire (Morgeson, 2006) was considered but as it does not measure the dimensions individually, Grant's 2008 measurement was considered more appropriate. An example from his scales is, 'My job allows frequent communication with the people who benefit from my work'. Following a pilot survey conducted for this study by five employees, as suggested by Rothgeb (2008), the researchers explained the term 'people who benefit from your work' more clearly in the introduction to the survey.

\section{Design}

Line managers provided the names and email addresses of employees. The researchers invited them, via email, to voluntary participate in the study. Data was collected via a web-based survey, accessed via a hyperlink included in the email. The first section of the survey collected biographical data and the second section consisted of a questionnaire combining the three questionnaires described above.

\section{Data analysis}

The researchers chose moderator regression models to examine relationships between the variables. A variance inflation factor (VIF) was calculated, to test for collinearity or ensure that the prediction of the outcome was independent (Enders, 2008). The results confirmed that all the VIFs were below 10 and that therefore there was no multicollinearity problem in terms of the explanatory variables being correlated with each other. The data was analysed by first conducting an analysis of variance test to examine the overall fit of the model for each hypothesis (Lewis-Beck, Bryman \& Futing Liao, 2004). The researchers used the $R$-square measures to test the predictive power of the regression and expressed them as percentages.

\section{Results}

The main and subconstructs of authentic leadership had a high Cronbach's alpha of 0.94 and the subconstructs were therefore reliable, as per definition of Gushta and Rupp (2010). The levels of authentic leadership, work engagement and beneficiary contact were all higher for males than females of the 81 responses and the higher level of work engagement for males is in line with previous findings where males have been found to have a higher work engagement than females on the UWES-9 (Schaufeli \& Bakker, 2004). There were varying levels of beneficiary contact across the tenure categories and there was no discernible pattern of relationships between tenure and authentic leadership, or with work engagement. These results are in line with the study by $\mathrm{Xu}$ and Thomas (2011) which found no relationship between tenure and work engagement. Males showed higher authentic leadership than females, in line with the findings of other studies (Monzani, Hernandez Bark, Van Dick \& Peiró, 2014). Mean scores of authentic leadership, work engagement and beneficiary contact across different business units indicated that levels of beneficiary contact were fairly similar across all of them. The mean, standard deviation and Cronbach's alpha are offered in Table 1. 
TABLE 1: Means, standard deviations, reliabilities (Cronbach's alpha) and Pearson's correlations for all variables.

\begin{tabular}{|c|c|c|c|c|c|c|c|c|c|c|c|c|c|c|c|c|}
\hline Variables & Mean & SD & Alpha & 1 & 2 & 3 & 4 & 5 & 6 & 7 & 8 & 9 & 10 & 11 & 12 & 13 \\
\hline 1. ALTR & 3.86 & 0.84 & 0.81 & - & - & - & - & - & - & - & - & - & - & - & - & - \\
\hline 2. ALME & 4.00 & 0.88 & 0.86 & $0.77 * * *$ & - & - & - & - & - & - & - & - & - & - & - & - \\
\hline 3. ALBP & 3.66 & 0.95 & 0.76 & $0.69 * * *$ & $0.66 * * *$ & - & - & - & - & - & - & - & - & - & - & - \\
\hline 4. ALSA & 3.46 & 1.00 & 0.87 & $0.72 * * *$ & $0.71 * * *$ & $0.78 * * *$ & - & - & - & - & - & - & - & - & - & - \\
\hline 5. $\mathrm{BCB}$ & 4.02 & 0.76 & 0.71 & 0.12 & 0.03 & 0.05 & 0.00 & - & - & - & - & - & - & - & - & - \\
\hline 6. $B C D$ & 4.10 & 0.80 & 0.77 & 0.16 & 0.06 & 0.08 & 0.06 & $0.76 * * *$ & - & - & - & - & - & - & - & - \\
\hline 8. WEV & 3.50 & 0.81 & 0.79 & $0.59 * * *$ & $0.53 * * *$ & $0.52 * * *$ & $0.50 * * *$ & $0.44 * * *$ & $0.37 * * *$ & $0.29 * *$ & - & - & - & - & - & - \\
\hline 9. WED & 3.82 & 0.81 & 0.82 & $0.48 * * *$ & $0.33 * *$ & $0.39 * * *$ & $0.31 * *$ & $0.53 * * *$ & $0.58 * * *$ & $0.47 * * *$ & $0.79 * * *$ & - & - & - & - & - \\
\hline 10. WEA & 3.88 & 0.87 & $\mathrm{n} / \mathrm{a}$ & $0.30 * *$ & $0.24 *$ & $0.33 * *$ & 0.17 & $0.38 * * *$ & $0.32 * *$ & $0.27 * * *$ & $0.66 * * *$ & $0.66 * * *$ & - & - & - & - \\
\hline 11. $A L$ & 3.76 & 0.81 & 0.94 & $0.90 * * *$ & $0.88 * * *$ & $0.86 * * *$ & $0.90 * * *$ & 0.06 & 0.10 & 0.07 & $0.60 * * *$ & $0.43 * * *$ & $0.29 * *$ & - & - & - \\
\hline 12. BC & 3.92 & 0.76 & 0.89 & 0.13 & 0.05 & 0.86 & 0.03 & $0.88 * * *$ & $0.88 * * *$ & $0.93 * * *$ & $0.39 * * *$ & $0.57 * * *$ & $0.35 * *$ & 0.08 & - & - \\
\hline 13. WE & 3.69 & 0.74 & 0.90 & $0.54 * * *$ & $0.43 * * *$ & $0.47 * * *$ & $0.40 * * *$ & $0.52 * * *$ & $0.52 * * *$ & $0.41 * * *$ & $0.92 * * *$ & $0.95 * * *$ & $0.75 * * *$ & $0.52 * * *$ & $0.52^{* * *}$ & - \\
\hline
\end{tabular}

ALTR, Authentic Leadership Relational Transparency; ALME, Authentic Leadership Internalised Moral Perspective; ALBP, Authentic Leadership Balanced Processing; ALSA, Authentic Leadership Self-awareness; BCB, Beneficiary Contact Breadth; BCD, Beneficiary Contact Depth; BCF, Beneficiary Contact Frequency; WEV, Work Engagement Vigour; WED, Work Engagement Dedication; WEA, Work Engagement Absorption; AL, Authentic Leadership; BC, Beneficiary Contact; WE, Work Engagement.

$*, p<0.05 ; * *, p<0.01 ; * *, p<0.001$

\section{Linear relationship and moderating effect of beneficiary contact}

The measurement of Hypothesis 1, that there is a linear relationship between authentic leadership and work engagement, resulted in the $R$-square confirming that $27.35 \%$ of the dependent variable, work engagement, was explained by the explanatory variable, authentic leadership. The parameter estimate of the authentic leadership variable was significant and illustrates that if authentic leadership increased by 1 standard deviation, work engagement would increase by 0.49 standard deviations.

As the analysis of variance test determined a significant $p$ value (less than 0.05), the researchers concluded that the overall fit of the model was significant. The $R$-square value confirmed that $51.73 \%$ of the dependent variable, work engagement, was explained by authentic leadership together with the moderating effect of beneficiary contact. All the $p$ values in this model were significant. The parameter estimate of the authentic leadership variable illustrated that if authentic leadership increased by 1 standard deviation (beneficiary contact was at the mean value, $\mathrm{BC}=0$ ), work engagement would increase by 0.45 standard deviations. The parameter estimate of the beneficiary contact variable illustrates that if beneficiary contact increased by 1 standard deviation, work engagement would increase by 0.48 standard deviations.

In contrast to what was expected, the moderating effect of beneficiary contact had a negative $\beta$ value of -0.17 . As the $p$ value of the moderator variable was significant, the researchers concluded that beneficiary contact had a moderating effect on the impact of authentic leadership on work engagement, and this moderating effect was negative. In order to assess the moderating effect of beneficiary contact at different levels in this model, Table 2 illustrates the moderating effect at higher and lower levels to the mean value of 0.45 .

This section describes the results of the moderator effect of the conditions of beneficiary contact, as discussed under
Hypothesis 3. Table 3 offers a summary of this hypothesis testing on the conditions of beneficiary contact. As the analyses of variance tests concluded significant $p$ values (less than 0.05 ) for the frequency, breadth and depth of beneficiary contact, the researchers determined that the overall fit of the models was significant. The $R$-square values confirmed that $42.22 \%, 52.73 \%$ and $51.54 \%$ respectively of the dependent variable, work engagement, were explained by these models of the explanatory variable, authentic leadership, together with the moderating effects of frequency, breadth and depth of beneficiary contact. The researchers concluded that frequency of beneficiary contact has no moderating effect on the impact of authentic leadership on work engagement, whereas depth and breadth $p$ values were significant.

The researchers investigated the individual constructs of work engagement as discussed under Hypothesis 2 and this section provides the results. Table 3 summarises these results. As analyses of variance tests concluded significant $p$ values (less than 0.05), the researchers inferred that the overall fit of the model was significant. The $R$-square value confirmed that $46.37 \%$ of the dependent variable, vigour of work engagement, $49.57 \%$ of dedication and $27.99 \%$ of absorption were explained by the model of the explanatory variable, authentic leadership, together with the moderating effects of beneficiary contact.

Beneficiary contact had no moderating effect on the impact of authentic leadership on vigour.

Interestingly, in the cases of dedication and absorption, the moderating effects were significant.

The researchers illustrated the results of the investigation around the beneficiary contact as a moderator on the impact of authentic leadership on work engagement in Figure 1.

\section{Discussion}

This study examined three hypotheses around the moderator effect of beneficiary contact on the relationship between authentic leadership and work engagement. The results 
TABLE 2: Linear relationship and moderating effect.

\begin{tabular}{lccc}
\hline Variables & Dependent variable: $d f$ & Work engagement: Parameter estimate & Standard error \\
\hline Authentic leadership & 1 & $0.45^{*}$ & 0.07 \\
Beneficiary contact $(B C)$ & 1 & $0.48^{*}$ & 0.07 \\
Moderator effect $(\beta)$ & 1 & $-0.17^{*}$ & 0.62 \\
Lower BC (mean -1$)$ & - & 0.27 & - \\
Higher BC (mean +1$)$ & - & - & 07 \\
\hline
\end{tabular}

$d f$, degrees of freedom; $\beta$, measure of moderator variable; Higher $\mathrm{BC}$, higher degree of beneficiary contact; Lower $\mathrm{BC}$, lower degree of beneficiary contact.

$*, p<0.05$

TABLE 3: Results of moderator regression analysis on beneficiary contact's effect on individual scales of authentic leadership and work engagement.

\begin{tabular}{|c|c|c|c|c|c|c|}
\hline Variable & $d f$ & $\Delta R^{2}$ & $\beta$ & SE & Higher BC & Lower BC \\
\hline BC Frequency (a) & 1 & 0.42 & -0.14 & 0.07 & $\mathrm{n} / \mathrm{a}$ & $\mathrm{n} / \mathrm{a}$ \\
\hline BC Breadth (b) & 1 & 0.52 & $-0.16^{*}$ & 0.07 & 0.29 & 0.63 \\
\hline BC Depth (c) & 1 & 0.51 & $-0.21 *$ & 0.07 & 0.24 & 0.67 \\
\hline WE Vigour (a) & 1 & 0.46 & -0.04 & 0.07 & $\mathrm{n} / \mathrm{a}$ & $n / a$ \\
\hline WE Dedication (b) & 1 & 0.49 & $-0.19 *$ & 0.07 & 0.16 & 0.55 \\
\hline WE Absorption (c) & 1 & 0.27 & $-0.34 *$ & 0.09 & -0.07 & 0.61 \\
\hline AL Transparency (a) & 1 & 0.51 & $-0.16 *$ & 0.06 & 0.26 & 0.59 \\
\hline AL Moral perspective (b) & 1 & 0.43 & -0.16 & 0.08 & $\mathrm{n} / \mathrm{a}$ & $\mathrm{n} / \mathrm{a}$ \\
\hline AL Balanced processing (c) & 1 & 0.44 & -0.08 & 0.06 & $\mathrm{n} / \mathrm{a}$ & $n / a$ \\
\hline AL Self-awareness (d) & 1 & 0.44 & $-0.20 *$ & 0.07 & 0.19 & 0.60 \\
\hline
\end{tabular}

$d f$, degrees of freedom; $\Delta R^{2}, R$-square values; $\beta$, measure of moderator variable; $\mathrm{SE}$, standard error; Higher $\mathrm{BC}$, higher degree of beneficiary contact; Lower $\mathrm{BC}$, lower degree of beneficiary contact; BC, beneficiary contact's; WE, work engagement; AL, authentic leadership.

Frequency (a), breadth (b) and depth (c) of beneficiary contact's moderating effect. Impact on individual constructs of work engagement, namely vigour (a), dedication (b) and absorption (c). $*, p<0.05$

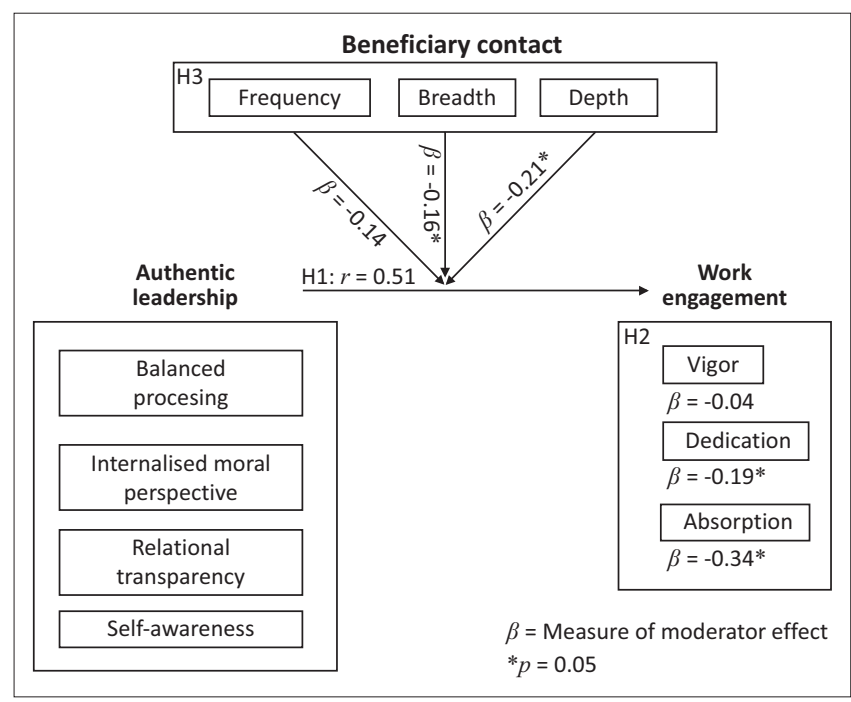

FIGURE 1: Illustration of results on individual constructs investigated in this study.

supported the outcomes of previous studies, where authentic leadership had a linear relationship with work engagement (Gardner et al., 2005; Ilies et al., 2005; Shamir \& Eilam, 2005). The implication for management is that developing authentic leaders will improve the work engagement of their employees.

The theoretical contribution of the study contributes the contingency theory notion of 'one size does not fit all'. The researchers asked whether the relationship between authentic leadership and work engagement would be universal, or be affected by situational variables, such as a job design allowing for frequency, breadth and depth of relational exchange with the beneficiaries of work. The moderator effect was indeed determined to be statistically significant. It was confirmed that, for the sample group, beneficiary contact weakened the positive effect of authentic leadership on work engagement, as illustrated in Figure 2.

At the authentic leadership level AL0 the level of work engagement is WE0. Beneficiary contact has the effect of shifting the line to the left and decreasing work engagement from WE0 to WE1 at the same level of authentic leadership, AL0. This finding is in line with Kenny's (2013) declaration that classically, moderation implies a weakening of a causal effect. The implications of this weakening effect means that leadership studies should take note of moderator effects and be careful of making claims about the universality of leaders' impact on followers' engagement. Leadership theory building should therefore expand its focus from leaderfollower exchanges to include exchanges between followers and the beneficiaries of their work.

Two competing perspectives on the effect of beneficiary contact were discussed earlier in this article's literary review. The first is the emotional labour and burnout perspective that frequent and emotionally intense interactions with customers and clients are likely to cause strain, stress and burnout (Bennett \& Barkensjo, 2005). Second is the job design perspective which holds that beneficiary contact allows employees to identify with, empathise with and understand beneficiaries. The results of this study support the emotional labour perspective, where higher levels of beneficiary contact decrease the positive impact of authentic leadership on work engagement.

The results revealed that affective communications, such as rude or hostile customer feedback, may have the effect of reducing motivation or performance (Grandley \& 


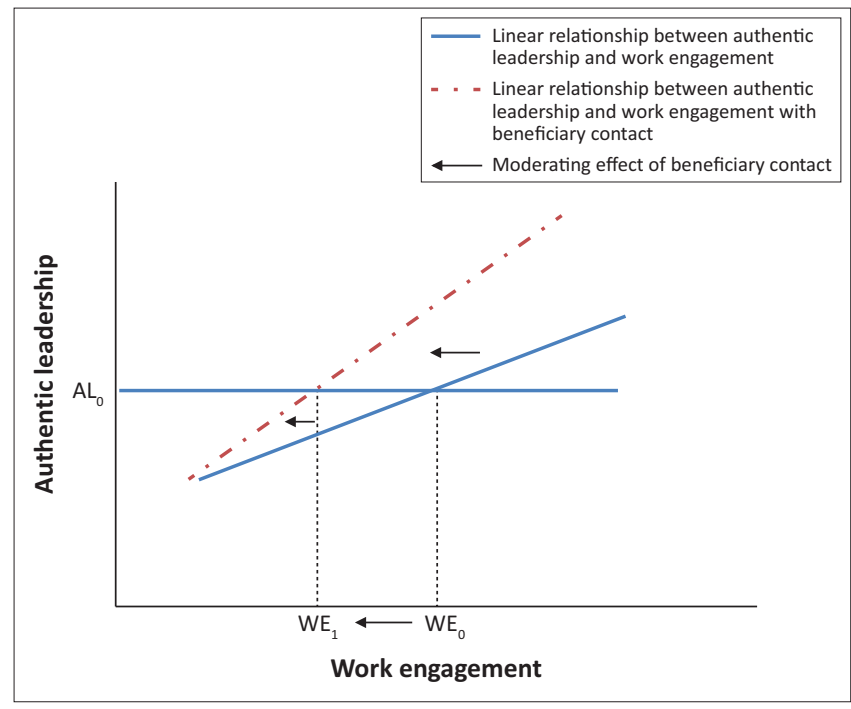

FIGURE 2: Graphical depiction of the moderating effect of beneficiary contact on the impact of authentic leadership on work engagement.

Diamond, 2010). The sample was composed of employees working in the financial services sector, which could be classified as an emotional labour occupation as customer interactions are a critical part of the job and customers may be more likely to act in a verbally abusive manner (Grandley et al., 2007). Grant, Fried, Parker and Frese (2010) emphasise that contemporary knowledge workers are exposed to challenging cognitive demands as well as an increase in emotional and interpersonal tasks in service work. The implications are that companies need to assess job roles, in terms of whether beneficiary contact results in higher or decreased levels of work engagement, and then design levels of beneficiary contact accordingly. For example, they could rotate employees between higher and lower levels, or between types of contact, such as frontline and back office roles.

\section{Outline of the results}

The individual constructs of beneficiary contact: Breadth, depth and frequency

The results of the data analysis in this study endorsed two of the individual constructs, breadth and depth of beneficiary contact, as having a moderating effect on the impact of authentic leadership on work engagement. The dimension of frequency was not statistically significant. The literature suggests that those employees that interact with beneficiaries frequently have a lower role ambiguity, as well as higher perceived task significance (Grandley \& Diamond, 2010). However, the results indicate that a higher frequency of beneficiary contact does not have a significant moderating effect. The literature does not provide evidence of the effect of breadth of beneficiary contact, whereas the results of this study indicated that if jobs are designed to have a variety of interactions with different beneficiaries, the impact of authentic leadership on work engagement will be decreased for this sample. Grant characterises depth of contact to be likely in service jobs, such as those of physician or counsellor (Grant, 2008) and it could be proposed that deep contact would be rare in the financial services industry. Thus, if jobs are designed to have opportunities for emotionally intense interactions with beneficiaries, the impact of authentic leadership on work engagement will be decreased. Leaders would need to adapt to these situations by purposefully increasing their authentic leadership, especially relational transparency and self-awareness to compensate for the difficulties that their followers are experiencing.

\section{Moderating effect on the individual constructs of work engagement}

The study substantiated some elements of Hypothesis 2, that beneficiary contact has a moderating effect on the impact of authentic leadership on the individual constructs of work engagement. Beneficiary contact did not have a significant effect on vigour. This ties in with the literature, where work engagement (vigour) and burnout (exhaustion) do not form opposite sides of the same continuum and were found to represent independent dimensions (Demerouti et al., 2010). For the sample group in this study, beneficiary contact decreased the impact of authentic leadership on dedication. This ties in with the literature, where work engagement (dedication) and burnout (cynicism or disengagement) were not considered to be each other's opposite (Demerouti et al., 2010), and the emotional labour and burnout focus of this dimension is confirmed. Dedication is an identification dimension, where emotional experiences, such as hostile or rude feedback, could affect enthusiasm and pride. Beneficiary contact also decreased the impact of authentic leadership on absorption. This could be explained by negative experiences with beneficiaries resulting in the employee losing selfconfidence and enthusiasm (Bennett \& Barkensjo, 2005), and therefore concentration. Being happily engrossed in one's work is decreased.

\section{Practical implications}

Leaders could increase work engagement in situations where clients are demanding by focusing on developing their followers' confidence and pride, as well as reinforcing their achievements and celebrating successes. It is not always possible to design jobs with lower levels, or varying levels, of beneficiary contact, and thus the organisation will need to find alternative means to counter this negative effect. Strain, stress and burnout are possible outcomes, and employees need to be trained on how to deal with difficult clients, and handle the stress of negative encounters. Management needs to be mindful of the potential for lower work engagement, and should implement other measures to increase work engagement, such as providing additional job resources (Bakker \& Demerouti, 2008), supporting employees to use their strengths (Van Woerkom, Bakker \& Nishii, 2016), cultivating shared group identity (Steffens, Haslam, Kerschreiter, Schuh \& van Dick, 2014) and increasing general organisational support (Rich, Lepine \& Crawford, 2010). Leadership development could benefit from this wider perspective, rather than focusing exclusively on increasing individual leaders' interpersonal skills. Without changing 
the structures within which these relationships are embedded, the return on leadership development investment might not be optimised. In line with contingency theories like the Pathgoal of House (1971), leaders need to adjust to situations in which their followers have intense exchanges with the beneficiaries of their work and make an extra effort to engage them under these circumstances.

\section{Limitations and recommendations}

The researchers ultimately restricted the sample to one financial services company and therefore the findings might be limited for use as a guide for financial services companies. The research was conducted as a cross-sectional study, which does not provide the depth of analysis of a longitudinal study. The research was limited to the focus on authentic leadership, and did not provide an analysis of the impact of various leadership styles. The research did not examine the other causal factors that influence work engagement, such as job resources or personality traits of employees. The study was limited to one financial services company and future studies should include a larger number of employees, across a variety of organisations, to examine consistency of results. Future research should address the role of different types of beneficiaries and investigate the moderating role that they have on work engagement. Further research should manipulate and measure the other leadership constructs, such as empowering leadership and transformational leadership, in this model. Further studies could investigate the moderating impact of numerous other organisational context variables, such as culture or climate, on authentic leadership.

\section{Conclusion}

This study focused on ascertaining whether beneficiary contact had a moderating effect on the impact of authentic leadership on work engagement, and drilled down into the variables within the individual constructs with the same objective. The moderating effect of beneficiary contact was concluded to be a negative effect, although not all of the results were deemed significant. The researchers proposed that the reason for beneficiary contact having a negative moderating effect, and thus decreasing the impact of authentic leadership on work engagement, was that beneficiary contact had an emotional labour and burnout focus, where emotionally intense interactions with beneficiaries were likely to cause strain, stress and burnout (Grant \& Parker, 2009). The following quote illustrates the negative effect that beneficiary contact possibly had on the sample group in this study:

In the public world of work, it is often part of an individual's job to accept uneven exchanges, to be treated with disrespect or anger by a client, all the while closeting into fantasy the anger one would like to respond with. (Hochschild, 1983, p. 86)

The study revealed how the impact of authentic leadership was contingent upon different types of beneficiary contacts.

\section{Acknowledgements Competing interests}

The authors declare that they have no financial or personal relationships which may have inappropriately influenced them in writing this article.

\section{Authors' contributions}

C.B.S. made conceptual contributions and was the research supervisor of the project. S.L.E. was responsible for performing the empirical study and C.B.S. was responsible for compiling the article.

\section{References}

Anitha, J. (2014). Determinants of employee engagement and their impact on employee performance. International Journal of Productivity and Performance Management, 63(3), 308-323. http://dx.doi.org/10.1108/IJPPM-01-2013-0008

Attridge, M. (2009). Measuring and managing employee work engagement: A review of the research and business literature. Journal of Workplace Behavioural Health 24, 383-398. http://dx.doi.org/10.1080/15555240903188398

Avolio, B.J. (2007). Promoting more integrative strategies for leadership theorybuilding. American Psychologist, 62, 25-33. http://dx.doi.org/10.1037/0003066X.62.1.25

Avolio, B.J., \& Gardner, W.L. (2005). Authentic leadership development: Getting to the root of positive forms of leadership. The Leadership Quarterly, 16, 315-338. http://dx.doi.org/10.1016/j.leaqua.2005.03.001

Avolio, B.J., Gardner, W.L., Walumbwa, F., Luthans, F., \& May, D.R. (2004). Unlocking the mask: A look at the process by which authentic leaders impact followe attitudes and behaviors. The Leadership Quarterly, 15, 801-823. http://dx.doi. org/10.1016/j.leaqua.2004.09.003

Avolio, B.J., Reichard, R.J., Hannah, S.T., Walumbwa, F.O., \& Chan, A. (2009). A metaanalytical review of leadership impact research: Experimental and quasiexperimental studies. The Leadership Quarterly, 20, 764-784. http://dx.doi. org/10.1016/j.leaqua.2009.06.006

Avolio, B.J., Walumbwa, F.O., \& Weber, T.J. (2009). Leadership: Current theories, research, and future directions. The Annual Review of Psychology, 60, 421-449. http://dx.doi.org/10.1146/annurev.psych.60.110707.163621

Axtell, C.M., Parker, S.K., Holman, D., \& Totterdell, P. (2007). Enhancing customer service: Perspective taking in a call centre. European Journal of Work and Organisational Psychology, 1-28. http://dx.doi.org/10.1080/13594320600989583

Bakker, A.B., \& Demerouti, E. (2007). The job demands-resources model: State of the art. Journal of Managerial Psychology, 22(3), 309-328. http://dx.doi.org/10.1108 /02683940710733115

Bakker, A.B., \& Demerouti, E. (2008). Towards a model of work engagement. Career Development International, 13(3), 209-223. http://dx.doi.org/10.1108/13620 430810870476

Bass, B.M. (1999). Two decades of research and development in transformational leadership. European Journal of Work and Organisational Psychology, 8(1), 9-32. http://dx.doi.org/10.1080/135943299398410

Bass, B.M., \& Steidlmeier, P. (1999). Ethics, character, and authentic transformational leadership behaviour. Leadership Quarterly, 10(2), 181-217. http://dx.doi. org/10.1016/S1048-9843(99)00016-8

Belle, N. (2012). Experimental evidence on the relationship between public service motivation and job performance. Public Administration Review, 73(1), 143-153. $\mathrm{http}: / / \mathrm{dx}$.doi.org/10.1111/j.1540-6210.2012.02621.x

Bennett, R., \& Barkensjo, A. (2005). Internal marketing, negative experiences, and volunteers' commitment to providing high-quality services in UK helping and caring charitable organization. Voluntas: International Journal of Voluntary and Nonprofit Organizations, 16(3), 251-274. http://dx.doi.org/10.1007/s11266-0057724-0

Burke, R.J., \& El-Kot, G. (2010). Work engagement among managers and professionals in Egypt. African Journal of Economic and Managament Studies, 1(1), 42-60. http://dx.doi.org/10.1108/20400701011028158

Cooper, C.D., Scandura, T.A., \& Schriesheim, C.A. (2005). Looking forward but learning from our past: Potential challenges to developing authentic leadership. The Leadership Quarterly, 16, 475-493. http://dx.doi.org/10.1016/j.leaqua.2005. 03.008

Crawford, E.R., LePine, J.A., \& Rich, B.L. (2010). Linking job demands and resources to employee engagement and burnout: A theoretical extension and meta-analytic test. Journal of Applied Psychology, 95(5), 834-848. http://dx.doi.org/10.1037/ a0019364

Day, D.V., Gronn, P., \& Salas, E. (2004). Leadership capacity in teams. The Leadership Quarterly, 15, 857-880. http://dx.doi.org/10.1016/j.leaqua.2004.09.001

Demerouti, E., Mostert, K., \& Bakker, A.B. (2010). Burnout and work engagement: A thorough investigation of the independency of both constructs. Journal of Occupational Health Psychology, 15(3), 209-222. http://dx.doi.org/10.1037/ a0019408 
Enders, F. (2008). Encyclopedia of epidemiology. Thousand Oaks, CA: Sage Publications.

Gallup, Inc. (2013). State of the American Workplace: Employee engagement insights for US business leaders. Washington, DC: Gallup, Inc.

Gardner, W.L., Avolio, B.J., Luthans, F., May, D.R., \& Walumbwa, F. (2005). 'Can you see the real me?' A self-based model of authentic leader and follower development The Leadership Quarterly, 16, 343-372. http://dx.doi.org/10.1016/j.leaqua.2005. 03.003

Gardner, W.L., Cogliser, C.C., Davis, K.M., \& Dickens, M.P. (2011). Authentic leadership A review of the literature and research agenda. The Leadership Quarterly, 22, 1120-1145. http://dx.doi.org/10.1016/j.leaqua.2011.09.007

George, B. (2003). Authentic leadership: Rediscovering the secrets to creating lasting value. San Francisco, CA: Jossey-Bass.

Grandley, A.A., \& Diamond, J.A. (2010). Interactions with the public: Bridging job design and emotional labor perspectives. Journal of Organizational Behavior, 31 338-350. http://dx.doi.org/10.1002/job.637

Grandley, A.A., Kern, J.H., \& Frone, M.R. (2007). Verbal abuse from outsiders versus insiders: Comparing frequency, impact on emotional exhaustion, and the role of insiders: Comparing frequency, impact on emotional exhaustion, and the role of
emotional labour. Journal of Occupational Health Psychology, 12(1), 63-79. http://dx.doi.org/10.1037/1076-8998.12.1.63

Grant, A.M. (2007). Job design and the motivation to make a prosocial difference. Academy of Management, 32(2), 393-417. http://dx.doi.org/10.5465/amr.2007. 24351328

Grant, A.M. (2008). Designing jobs to do good: Dimensions and psychological consequences of prosocial job characteristics. The Journal of Positive Psychology, 3(1), 19-39. http://dx.doi.org/10.1080/17439760701751012

Grant, A.M. (2012). Leading with meaning: Beneficiary contact, prosocial impact, and the performance effects of transformational leadership. Academy of Management Journal, 55(2), 458-476. http://dx.doi.org/10.5465/amj.2010.0588

Grant, A.M., Campbell, E.M., Chen, G., Cottone, K., Lapedis, D., \& Lee, K. (2007) Impact and the art of motivation maintenance: The effects of contact with beneficiaries on persistence behavior. Organizational Behavior and Human Decision Processes, 103, 53-67. http://dx.doi.org/10.1016/j.obhdp.2006.05.004

Grant, A.M., Fried, Y., Parker, S. \& Frese, M. (2010). Putting job design in context: Introduction to the special issue. Journal of Organizational Behaviour, 31, 145-157. http://dx.doi.org/10.1002/job.679

Grant, A.M., \& Parker, S.K. (2009). Redesigning work design theories: The rise of relational and proactive perspectives. The Academy of Management Annuals, 3(1), 317-375. http://dx.doi.org/10.1080/19416520903047327

Gushta, M.M., \& Rupp, A.A. (2010). Encyclopedia of research design. Thousand Oaks, CA: Sage Publications, Inc.

Harter, J.K., Hayes, T.L., \& Schmidt, F.L. (2002). Business-unit-level relationship between employee satisfaction, employee engagement, and business outcomes: A meta-analysis. Journal of Applied Psychology, 87(2), 268-279. http://dx.doi. org/10.1037/0021-9010.87.2.268

Hassan, A., \& Ahmed, F. (2011). Authentic leadership, trust and work engagement. International Journal of Human and Social Sciences, 6(3), 164-170.

Hochschild, A.R. (1983). The managed heart: Commercialization of human feeling. Berkeley, CA: University of California Press.

House, R.J. (1971). A path goal theory of leader effectiveness. Administrative Science Quarterly, 16, 321-338. http://dx.doi.org/10.2307/2391905

Humphrey, S.E., Nahrgang, J.D., \& Morgeson, F.P. (2007). Integrating motivational, social, and contextual work design features: A meta-analytic summary and theoretical extension of work design literature. Journal of applied psychology, 92, 1332-1356. http://dx.doi.org/10.1037/0021-9010.92.5.1332

llies, R., Morgeson, F.P., \& Nahrgang, J.D. (2005). Authentic leadership and eudaemonic well-being. The Leadership Quarterly, 16, 373-394. http://dx.doi.org/10.1016/j. leaqua.2005.03.002

Kahn, W. (1990). Psychological conditions of personal engagement and disengagement at work. Academy of Management Journal, 33, 692-724. http://dx.doi. org/10.2307/256287

Kenny, D. (2013). Moderator variables: Introduction. Retrieved November 20, 2014 from http://davidakenny.net/cm/moderation.htm\#GO

Koene, B.A., Vogelaar, A.L., \& Soeters, J.L. (2002). Leadership effects on organizational climate and financial performance: Local leadership effect in chain stores. The climate and financial performance: Local leadership effect in chain stores. The
Leadership Quarterly, 13, 193-215. http://dx.doi.org/10.1016/S1048Leadership Quarte

Leroy, H., Palanski, M.E., \& Simons, T. (2012). Authentic leadership and behavioural integrity as drivers of follower commitment and performance. Journal of Business integrity as drivers of follower commitment and performance. Journal
Ethics, 107, 255-264. http://dx.doi.org/10.1007/s10551-011-1036-1

Lewis-Beck, M.S., Bryman, A., \& Futing Liao, T. (2004). The SAGE Encyclopedia of social science research methods. Thousand Oaks, CA: Sage Publications.

Llorens, S., Bakker, A.B., Schaufeli, W., \& Salanova, M. (2006). Testing the robustness of job demands-resources model. International Journal of Stress Management 13(3), 378-391. http://dx.doi.org/10.1037/1072-5245.13.3.378

Lord, R., \& Hall, R. (1992). Contemporary views of leadership and individual differences. The Leadership Quarterly, 3, 137-157. http://dx.doi. org/10.1016/1048-9843(92)90030-J

Maslach, C., Jackson, S.E., \& Leiter, M. (1996). Maslach burnout inventory: Manual. (3rd edn.). Palo Alto, CA: Consulting Psychological Press.

Maslach, C., Leiter, M.P., \& Jackson, S.E. (2012). Making a significant difference with burnout interventions: Researcher and practitioner collaboration. Journal of Organizational Behaviour, 33, 296-300. http://dx.doi.org/10.1002/job.784
Monzani, L., Hernandez-Bark, A., Van Dick, R., \& Peiró, J.M. (2014). The synergistic effect of prototypicality and authenticity in the relation between leaders' biological gender and their organizational identification. Journal of Business Ethics, 132, 737-752. http://dx.doi.org/10.1007/s10551-014-2335-0

Morgeson, F.H., \& Humphrey, S.E. (2006). The Work Design Questionanaire (WDQ): Developing and validating a comprehensice measure for asessing job design and the nature of work. Journal of Applied Psychology, 91(6), 1321-1339. http://dx. the nature of work. Journal of Applied
doi.org/10.1037/0021-9010.91.6.1321

Padilla, A., Hogan, R., \& Kaiser, R.B. (2007). The toxic triangle: Destructive leaders, susceptible followers, and conducive environments. The Leadership Quarterly, 18 , susceptible followers, and conducive environments. The Leadr
176-194. http://dx.doi.org/10.1016/j.leaqua.2007.03.001

Parker, S., \& Axtell, C. (2001). Seeing another viewpoint: Antecedents and outcomes of employee perspective taking. Academy of Management Journal, 44(6), 1085-1100. $\mathrm{http}: / /$ dx.doi.org/10.2307/3069390

Pawar, B.S., \& Eastman, K.K. (1997). The nature and implications of contextual influences on transformational leadership: A conceptual examination. Academy of Management Review, 22(1), 80-109.

Porter, L.W., \& McLaughlin, G.B. (2006). Leadership and the organisational contex: Like the weather? The Leadership Quarterly, 17, 559-576. http://dx.doi.org/10.1016/j. leaqua.2006.10.002

Rich, B.L., Lepine, J.A., \& Crawford, E.R. (2010). Job engagement: Antecedents and effects of job performance. Academy of Management Journal, 53(3), 617-635. http://dx.doi.org/10.5465/AMJ.2010.51468988

Rothgeb, J.R. (2008). Encyclopedia of survey research methods. Thousand Oaks, CA: Sage Publications, Inc.

Saks, A. (2006). Antecedents and consequences of employee engagement. Journal of Managerial Psychology, 21(7), 600-619. http://dx.doi.org/10.1108/02683940 610690169

Salanova, M., Agut, S., \& Peiró, J.M. (2005). Linking organizational resources and work engagement to employee performance and customer loyalty: The mediation of service climate. Journal of Applied Psychology, 96(6), 1217-1227. http://dx.doi. org/10.1037/0021-9010.90.6.1217

Saunders, M., \& Lewis, P. (2012). Doing research in business and management: An essential guide to planning your project. Essex: Pearson Education Limited.

Schaufeli, W., \& Bakker, A. (2004). UWES: Utrecht work engagement scale prelimenary manual, 1.1. Utrecht: Occupational Health Psychology Unit Utrecht University.

Schaufeli, W., Bakker, A., \& Salanova, M. (2006). The measurement of work engagement with a short questionnare. Education and Psychological Measurement, 66(4), 701-716. http://dx.doi.org/10.1177/0013164405282471

Schaufeli, W., Salanova, M., Gonzalez-Roma, V., \& Bakker, A. (2002). The measurement of engagement and burnout: A confirmatory analytic approach. Journal of Happiness Studies, 3, 71-92. http://dx.doi.org/10.1023/A:1015630930326

Seligman, M., \& Csikzentmihalyi, M. (2000). Positive psychology: An introduction. American Psychologist, 55, 5-14. http://dx.doi.org/10.1037/0003-066X.55.1.5

Shamir, B., \& Eilam, G. (2005). 'What's your story?' A life-stories approach to authentic leadership development. The Leadership Quarterly, 16, 395-417. http://dx.doi. org/10.1016/j.leaqua.2005.03.005

Shamir, B., \& Howell, J.M. (1999). Organizational and contextual influences on the emergence and effectiveness of charasmatic leadership. Leadership Quarterly, 10(2), 257-283. http://dx.doi.org/10.1016/S1048-9843(99)00014-4

Shuck, B., Reio, T., \& Rocco, B. (2011). Employee engagement: An examination of antecedent and outcome variables. Human Resource Development International, 14(4), 427-445. http://dx.doi.org/10.1080/13678868.2011.601587

Simpson, M.R. (2009). Engagement at work: A review of the literature. Internationa Journal of Nursing Studies, 46, 1012-1024. http://dx.doi.org/10.1016/j ijnurstu.2008.05.003

Steffens, N.K., Haslam, A., Kerschreiter, R., Schuh, S.C., \& van Dick, R. (2014). Leaders enhance group members' work engagement and reduce their burnout by crafting social identity. German Journal of Research in Human Resource Management 28(1-2), 173-194. http://dx.doi.org/10.1177/239700221402800110

Tosi, H.L. (1991). The organization as a context for leadership theory: A multilevel approach. The Leadership Quarterly, 2, 205-228. http://dx.doi.org/10.1016/10489843(91)90011-P

Towers Watson. (2012). 2012 Global workforce study. London: Towers Watson.

Uhl-Bien, M., Marion, R., \& McKelvey, B. (2007). Complexity leadership theory: Shifting leadership from the industrial age to the knowledge era. The Leadership Quarterly, (18), 298-318. http://dx.doi.org/10.1016/j.leaqua.2007.04.002

Van den Heuvel, M., Demerouti, E., Bakker, A.B., \& Schaufeli, W.B. (2013). Adapting to change: The value of change information and meaning-making. Journal of Vocational Behavior, 83, 11-21. http://dx.doi.org/10.1016/j.jvb.2013.02.004

Van Woerkom, M., Bakker, A.B., \& Nishii, L.H. (2016). Accumulative Job demands and support for strengths use: Fine-tuning the job demands-resources model using conservation of resources theory. Journal of Applied Psychology, 101(1), 141-150. conservation of resources theory. Journ
http://dx.doi.org/10.1037/apl0000033

Walter, F., \& Bruch, H. (2010). Structural impacts on the occurrence and effectiveness of transformational leadership: An empirical study at the organizational level of analysis, The Leadership Quarterly, 21, 765-782. http://dx.doi.org/10.1016/j. analysis, The Leadersh

Walumbwa, F.O., Avolio, B.J., Gardner, W.L., Wernsing, T.S., \& Petersen, S.J. (2008). Authentic Leadership: Development and Validation of a Theory-Based Measure? Journal of Management, 34(89), 89-126. http://doi.org/10.1177/014920630 7308913 
Xanthopoulou, D., Bakker, A.B., Demerouti, E., \& Schaufeli, W.B. (2012). A diary study on the happy worker: How job resources relate to positive emotions and personal resources. European Journal of Work \& Organizational

$\mathrm{Xu}$, J., \& Thomas, H.C. (2011). How can leaders achieve high employee engagement? Leadership and Organization Development Journal, 32(4), 399-416. http://dx.doi. org/10.1108/01437731111134661
Yukl, G. (1999). An evaluation of conceptual weakness in transformational and charismatic leadership theories. The Leadership Quarterly, 10, 285-305. http:// dx.doi.org/10.1016/S1048-9843(99)00013-2

Yukl, G., O'Donnell, M., \& Taber, T. (2009). Leader behaviors and leader member exchange. Journal of Managerial Psychology, 24(4), 289-299. http://dx.doi. org/10.1108/02683940910952697 